RUSLAN DELIATYNSKYI,

Ivano-Frankivsk Academy of John Chrysostom (Ivano-Frankivsk, Ukraine)

e-mail: r.deliatynskyi@ukr.net, ORCID 0000-0002-6020-7666

VASYL GOGOL,

Ivano-Frankivsk Academy of John Chrysostom (Ivano-Frankivsk, Ukraine)

e-mail: otets.vasyl.gogol@ukr.net, ORCID0000-0001-5236-885X

ALINA ZADOROZHNIA,

The National Historical and Ethnographic Reserve "Pereyaslav" (Pereyaslav, Ukraine)

e-mail: alina0906@ukr.net, ORCID0000-0002-9537-9054

\title{
BLESSED KLYMENTIY SHEPTYTSKY (1869-1951) IN THE LIGHT OF CONTEMPORARY DOMESTIC HISTORIOGRAPHY
}

\begin{abstract}
The article is devoted to the historiographical analysis and generalization of achievements of representatives of the contemporary domestic historiography (1990-2020), taking into consideration the works of scholars of the diasporic historiography, who explored the life path and activity of Blessed Hieromartyr Klymentiy (Casimir) count Sheptytsky (1869-1951). It has been noted that studies of the biography of Klymentiy Sheptytsky, initiated by diasporic scholars, contributed to the elucidation mainly of church-religious activity, avoiding the early period of his biography, and Soviet historiography put mistaken ideological stamps regarding the "brother of the metropolitan". The authors emphasize that the growth of scientific interest in the biography of Klymentiy Sheptytsky, stimulated by the revival of the UGCC structures in general and the Studite monasticism in particular, manifested itself in two directions: search and systematization of sources, formation of specialized archives, publication of new studies on the history of the Studites and the activity of their hegumen. Dividing the studies of contemporary domestic historians and theologians into two periods (in the 1990s and 2000s), the authors note that they were first related to the preparation for the Beatification of Klymentiy (2001), and then with the popularization and in-depth study of his heritage for use in the practice of memorialization and spiritual life of the Studites' Order. Therefore, there is an increase in the number and differentiation of studies of the activities of Blessed Klymentiy in period from the time of his entry to the monastery until his exile and death. The formed imbalance in the coverage of his biography, which consisted in "ignoring" the early period and creating new "myths", were resolved in the monographs of V. Chornopyska and I. Matkovskyi, in which his genealogy, all stages of the life path, socio-political and religious activities were described in detail.
\end{abstract}

Keywords: diasporic historiography; Soviet historiography; contemporary domestic historiography; count Casimir Sheptytsky; Klymentiy Sheptytsky; Studites' Order; UGCC Blessed New Martyrs.

Introduction

The celebration of the 150th birth anniversary of Klymentiy Sheptytsky (2019) prompted the public to popularize, and scholars - to study complementarily the biography of one of the Blessed New Martyrs for the faith of the Ukrainian Greek Catholic Church (UGCC) of the 20th century. The need for an objective reconstruction of the life and work of Klymentiy Sheptytsky, caused by the insufficient attention of representatives of Ukrainian diasporic historiography (A. Amman \& M. Stek; K. Korolevskiy; P. Senytsia; O. Zinkevych and T. Lonchyna, V. Lentsyk), to him, ideological stereotypes in Soviet historiography (S. Danylenko; K. Dmytruk), gradually were "solved" in contemporary Ukrainian historiography of the 1990s-2000s (N. Pikulyk i L. Senyk; S. Dmytrukh; V. Chornopyska; I. Matkovskyi). However, according to one of the researchers, even despite recent studies, some pages of the biography and activities of Blessed Klymentiy are still waiting for future researchers (Matkovskyi, 2019: 15, 87, 95, 111, 124, 127, 192, 275, $301,319,374,469,479,486)$.
The purpose of this study is to conduct a historiographical analysis and summarize the achievements of researchers - representatives of the Ukrainian diasporic, Soviet and contemporary domestic historiography in the reconstruction of the biography, socio-political and religious activities of Blessed Klymentiy (Casimir) count Sheptytsky (1869-1951) in the context of socio-political processes in Galicia at the end of the 19th - the first half of the 20th century, as well as to identify "unsolved" problems that require additional studies.

\section{Methods}

The basic scientific approaches in the study of the figure of Klymentiy (Casimir) Sheptytsky are principles of objectivity and historicism, that take into account the influence of various factors - from socio-political conditions to family traditions and personal motives - in his life and work. Both general scientific (analysis and synthesis, induction and deduction, classification and systematization) and special (problem-chronological, comparative-historical) methods 
have been used in the study. Leading methods in the study are the biographical method, which allows to show objectively the civic and religious activities of Klymentiy (Casimir) Sheptytsky, and the method of historiographical analysis, which involves the analysis of results achieved by historians, that have become scientific facts, and define the range of scientific issues that require search for additional and / or interpretation of known sources, and in general to conduct complementary scientific research.

\section{Materials and results of the study}

In contemporary domestic historiography of the early 21st century, the figure of Klymentiy (Casimir) Sheptytsky is already more "recognizable" among other prominent church figures - hierarchs and priests of the UGCC of the first half of the 20th century, even in comparison with the domestic historiography of the 1990s, in which, against the background of "religious revival" in independent Ukraine, there was a "historiographical boom" of interest in the history of the UGCC from the Union of Brest in general and, especially, in the first half of the 20th century. Thus, in contemporary domestic historiography, information about the biography and activities of Hegumen Klymentiy Sheptytsky, known since 2001 as the Blessed New Martyr of the UGCC, has been gradually formed, supplemented and expanded, relying partly on the achievements of diasporic and foreign historiography, and therefore was based on the study and involvement of new sources in the scientific circulation.

Ukrainian diasporic and foreign Church Historian established the beginning of the study of the biography of Klymentiy Sheptytsky. Thus, Professor of the Pontifical Oriental Institute in Rome A. Amman and a Studite jerm. M. Stek were one of the first to publish the work "Monks of the Studite Rite", in which they described the role of Archimandrite Klymentiy and Metropolitan Andrei in the development of Studite monasticism as a cultural and religious center of Ukrainians in Eastern Galicia. It was A. M. Amman who first offered the opinion that "Hegumen Klymentiy is the right hand of the Metropolitan" (Amman \& Stek, 1955: 30). Later, a staff member of the Vatican Library and an assistant to Andrei Sheptytsky in Rome, Fr. Kyrylo Korolevsky (Jean-François Sharon) devoted a separate section of a biographical study on the Galician Metropolitan, first published in French by the Ukrainian Theological Scientific Society in Rome (Korolevskiy, 1964) and republished in translation in Ukrainian in Lviv (Korolevskiy, 2014), to the processes of restoration of Galician monasticism by Metropolitan, mentioned Amman's stay in the Univ Lavra and the peculiarities of the approval of the "Typikon" by the Holy See, and also described for the first time the stay of Fr. Klymentiy in prison (Korolevskiy, 1964: 260-283). Separate articles in the collection "The lamp of truth: sources for the history of the Ukrainian Catholic Theological Academy in Lviv" (Senytsia, 1973; Senytsia, 1983) contributed to the expansion of knowledge about the biography of the first Studite Archimandrite Klymentiy, in particular: by Fr. M. Hrynchyshyn, CSsR - about the arrest and exile of Fr. Klymentiy (1983: 471-475), by Count I. L. Sheptytsky - a biographical essay about his uncle, Hegumen Fr. Klymentiy (1983: 776-782), by V. Hordynskyi - about the Studite fathers and the Sheptytsky brothers (1983: 463-468). After all, the compilers of the collection of documents about the UGCC O. Zinkevych and Fr. T. R. Lonchyna collected meticulously separate facts about the life and work of Fr. Klymentiy Sheptytsky, in particular: about the participation of the Hegumen in the revival of monastic life under the Rite of St. Theodore of Studium, the appointment of the UGCC Exarch of Russia and Siberia and his approval by the decision of Pope Pius XII $(1939,1941)$, discussion on the candidacy of Fr. Klymentiy as an auxiliary bishop for the brother-metropolitan among the clergy of the Lviv Archeparchy (1939), participation in the meetings of the Archeparchial Council and the Council of Exarchs (1940), the presence of Fr. Klymentiy in the final moments of Metropolitan Andrei's life and at his funeral (November 1944), appointment as Archimandrite of Studites, visit to Moscow as a head of the UGCC delegation on behalf of Metropolitan Josyf Slipyi (1944), unsuccessful contacts with Roman Shukhevych, the Head of the UPA, appointment of J. Slipyi to one of the administrators of the Lviv Archeparchy (April 1944), arrest, exile to concentration camps in Vladimir-onKlyazma and death (erroneously in 1958) (1985: 30, 60, 63-64, 65, 66, 67, 153, 195, 201, 203, 205, 209, 216, 239, $297,382,459-460,474,519)$. A kind of summary of diasporic historiography can be considered a short encyclopedic article by V. Lentsyk about Fr. Klymentiy Sheptytsky, which outlines the main stages of his life: it is stated that Klymentiy (Casimir) was an ambassador of the Sejm of Galicia and the Viennese parliament, in 1911 entered the Studite monastery, became Hegumen, complied the "Typikon", since 1939 was a member of the Metropolitan Rutsky Ukrainian Catholic Institute of Church Unity and secretly appointed as Exarch of Russia and Siberia, arrested in 1947, sentenced to 25 years and died in exile, and it is suggested that he "was a secret bishop because he ordained prisoners of different nationalities" (Lentsyk, 1984: 3845). Thus, diasporic researchers focused on the church and religious activities of Klymentiy Sheptytsky, his collaborative work with Metropolitan Andrei, bypassing the early period of his biography.

For completeness of historiographical analysis, it should be noted that in Soviet historiography the person of Klymentiy Sheptytsky was accompanied by ideological stereotypes or almost complete disregard (Danylenko, 1970; Dmytruk, 1988: 240), therefore, not "burdened" even with factual material, it is of no value for further research of his biography.

Since the legalization of the UGCC (1989) and the revival of state independence of Ukraine (1991), Ukrainian domestic historiography dedicated to the history of the UGCC has overcome old ideological stereotypes, its representatives have tried to take into account as much achievements of diasporic and foreign historiography as possible, to open new, previously classified or little-known archival documents, to involve materials of "oral history". Thus, V. Serhiichuk initiated the publication of a series of declassified documents on the forcible liquidation of the UGCC in 1945-1946 and the development of the "Catacomb" Church (1997; 2001), which contained information about repressed hierarchs and priests, in particular, about Studite Hegumen Fr. Klymentiy Sheptytsky. Another important direction of scientific studies on the history of the UGCC in the 20th century was the research project of the Institute of Church History of the Ukrainian Catholic University "Profiles of Fortitude: An Oral History of the Clandestine Life of the Ukrainian Greek-Catholic Church, 1946-1989" (Gudziak, 2000: 5-9) launched in 1992, within which an archive was formed on the basis of collected documents and memoirs of living witnesses $(\mathrm{AICH})$, in particular there were materials about Klymentiy Sheptytsky, which were partially used later by historian Yu. R. Skira (2017: 184-185).

The revival and development of the organizational structures of the UGCC, its monastic ranks and congregations, in the early 1990s gradually stimulated the interest of the scientific, church and civil community in the history of the Studites, their most prominent representatives, 
including Hegumen, then Archimandrite Klymentiy Sheptytsky. Since then, the scientific heuristic and research work has continued at least in two main directions: firstly, an active search for new sources in the state archives of Ukraine (the Central State Historical Archives of Ukraine in Lviv (TsDIAL), the Sectoral State Archive of the Security Service of Ukraine (GDA SBU), the State Archives of Lviv Region (DALO) and others) and their publication, collection of evidence (interviews) using the method of "oral history", their partial publication and the formation of the archives of monasteries of the Studite Rite - Univ Holy Dormition Lavra (ASUL), the St. John's Lavra of the Studite Rite (ASIL), the Intercession (Pokrovsky) Convent of the Studite Rite (ASPM), Postulation Center of monasteries of the Studite Rite (PTsMSU) and Postulation Center for the Beatification and Canonization of Saints of the UGCC (UGCC PTsBiKS) have been conducted; secondly, scientific research and popularization of the history of the monasteries of the Studite Rite, religious-church, public and cultural-educational activities of the Studite monks have been conducted through scientific-practical conferences and popular science events, preparation and publication of scientific and journalistic papers. As a result of this work, the remarkable individual of Klymentiy Sheptytsky have acquired clearer outlines in domestic historiography.

I. Parashchak (1994) and M. Marushchak (1995) were one of the first domestic researchers of Klymentiy Sheptytsky's biography, who showed the last period of his life (1947-1951) in publicistic articles, emphasized the juristic unlawfulness of actions of the Soviet government authorities regarding conviction of the Archimandrite, showed his persistence in religious and national beliefs. L. Kyrychuk (1995) showed the role of Klimenty Sheptytsky in the life of the UGCC in the context of the establishment of Soviet power in 1944-1946 and emphasized the need for a more thorough study of the activities of metropolitan' brother. The issue of charitable activity of Archimandrite Klymentiy (Sheptytsky) became an object of study in the articles by K. Hrytsyna (1994). The most important "turning points" in the life of Klymentiy (Casimir) Sheptytsky were traced in journalistic essays by K. Labinska (1999; 2006) and O. Saiko (2000).

The available information about the martyr's death of Klymentiy Sheptytsky became the basis for the preparation of documents for the beatification process, which was sought to begin in the 1980s (Lentsyk, 1984: 3845), but officially began in 1996 at the initiative of the UGCC hierarchy (Chornopyska, 2014: 28). This prompted the scientific community to conduct a thorough study of the biography of Klymentiy Sheptytsky. Thus, in 1996, a book by Yan Casimir Sheptytsky, nephew of Metropolitan Andrey and Hegumen Klymentiy, written in 1990 in French and republished in translation by N. Pikulyk, L. Senyk and J. Maksymovych, was first published in Lviv. The book reconstructs the events of childhood, education and political activity before entering the monastery, and therefore, considering the loss of part of the family archives during the Second World War, briefly describes the activities of Hegumen of the Studites Klymentiy (Sheptytskyi, Ya. K., 1996). Later, N. Pikulyk and L. Senyk, using the mentioned book and additional sources, published a scientific-journalistic essay "Klymentiy Sheptytsky - Servant of God" (1997), in which they tried to show comprehensively the childhood and youth of Count Casimir; admission to the monastery, monastic life and activity as Hegumen and Archimandrite Klymentiy. J. K. Sheptytsky's book was republished for the second time by "Svichado" Publishing House (2016), and its fragments were published as

ISSN 1728-9343 (Print)

ISSN 2411-3093 (Online) memoirs in the thematic collection "Archimandrite Klymentiy Sheptytsky" by the Intercession (Pokrovsky) Convent of the Studite Rite (Sheptytskyi, 2001: 22-25).

In addition, significant source-studying work has been conducted and, for the first time in independent Ukraine, new sources on the history of the Studites have been published. Thus, the "Svichado" Publishing House in Lviv first published a collection of normative documents of the Studite Rite "Typikon", prepared in the 1920s and 1940s by Metropolitan Andrey Sheptytsky and Hegumen Klymentiy Sheptytsky, translated into French and submitted to the Vatican City through Fr. K. Korolevsky, and then, in the early 1990s, translated into Ukrainian by hieromonks N. Deinega and Yu. Voronovsky (Typikon, 1996). Later, this document was republished with annexes (Typikony, 2007). Meanwhile, as part of the scientific program of the Rome-based Pope St. Clement Ukrainian Catholic University Archbishop Miroslav Marusyn published a historical-theological essay on the Rite of St. Theodore in Ukraine from the beginnings of monasticism in Rus-Ukraine to the beginning of the 20th century, at the end of which he published the "Studite Rite" by Metropolitan Andrey Sheptytsky approved by hierarchs of the Metropolis of Halych on August 30, 1906 (Marusyn, 1995). It was this Rite of 1906 that became the basis for the Typikon, which was prepared by Fr. Klymentiy. Therefore, several other documentary publications contributed to the coverage of the biography of the Hegumen of the Studites. Thus, the diasporic historian and theologian A. Babiak organized and published the minutes of the meetings of the Lviv Archeparchial Councils of 19401944 , on the pages of which the data on the participation of Hegumen of the Studites Klymentiy Sheptytsky (2000) was preserved. The publication of declassified documents of the USSR KGB bodies by V. Serhiichuk in several thematic collections on the forcible liquidation of the UGCC in 1945-1946 (2006), on Metropolitan A. Sheptytsky (2005), and a collection of documents "On the Way of the Cross..." edited by M. Haikovsky (2006) also helped to reveal new circumstances of activity and arrest of Hegumen Klymentiy Sheptytsky.

The historical essay "Vineyard of the Lord" by famous Lviv historian P. Shkrabiuk (1995), in which the researcher, reconstructing the biography of Fr. Joseph Kladochny, a close associate of the metropolitan, published memoirs about the daily life of the Studite monks and one of the works by Klymentiy Sheptytsky (1995: 105-109, 221-223). contributed to advanced studies and popularization of individual pages of the biography of Hegumen of the Studites Fr. Klymentiy. A comprehensive historical essay about the Univ Holy Dormition Lavra from the end of the 13th to the end of the 20th century was published for the first time in independent Ukraine by the historian I. Mytsko, who, on the basis of significant factual material, described the activities and outlined the national and cultural role of the Studites, as well as for the first time formed biograms of monks of Univ Monastery from the 15th century to 1939, including Fr. Klymentiy Sheptytsky (1998: 86-111, 254-316). In their historical investigation of the Studites in the Hutsul region, the hieromonks Oleksandr Prylip and Theodore Martyniuk mentioned the support of Fr. Klymentiy in the foundation of the monastery (1998).

After a careful study of the circumstances of life and work of Fr. Klymentiy Sheptytsky at the level of the Lviv Archeparchy of the UGCC, the archeparchial process was completed on March 2, 2001, and documents containing the biography, information about the martyr's death and theological analysis of his works were sent to the Apostolic Capital. On April 24, in the presence of Pope John Paul II,

SKHID No. 2 (166) March-April 2020 
the decree of martyrdom, heroic virtues and miracles of Fr. Klymentiy among other 28 Servants of God of the UGCC was proclaimed, and on June 27, 2001, during a visit to Ukraine, Pope John Paul II proclaimed decrees on beatification again (UHKTs, 2001). The biography of Blessed Klymentiy, as well as other New Martyrs, which became the basis for the beatification process, soon was published in the form of popular science essays by historians A. Babiak (2002) and O. Turii (2005). Hieromonk Sebastian Dmytrukh, on the basis of an analysis of the scientific and theological heritage and memoirs of the Hegumen's contemporaries, showed the influence of Klymentiy on the spiritual formation of Studite monks (1997), identified such factors of their formation as prayer, church rules, reading of the Holy Scriptures and spiritual meditation helping to deepen the spirituality of the monk. Separately, S. Dmytrukh analyzed the last years of life (1947-1951) on the basis of the declassified criminal case of Klimenty Sheptytsky (2002: 23, 108, 117-124).

Thus, the first studies of the biography of Fr. Klymentiy Sheptytsky by domestic historians and theologians were connected mainly with the preparation for his beatification in 2001, while a new wave of interest in his figure in the 2000s - 2010s was due to the need to popularize knowledge about the New Martyr of the UGCC among believers, the formation of public memory (memorialization) of modern Ukrainian society, as well as the study of his activities and artistic heritage for practical use in the organization of the spiritual life of the monasteries of the Studite Rite.

Growth of the scientific interest in the biography of Blessed Klymentiy Sheptytsky, problems of history and theological heritage of the monasticism of the Studite Rite at the beginning of the 21st century has been manifested in the organization of scientific conferences, increase in the number and expansion of topics of scientific, historiographic and journalistic publications, organizing and multiplying the funds of the above-mentioned archives of monasteries of the Studite Rite.

An important historiographical source was the thematic issues by the Intercession (Pokrovsky) Convent of the Studite Rite "Archimandrite Klymentiy Sheptytsky" (2001a; 20016; 2002), which for the first time collected Klymentiy Sheptytsky's scientific and theological works, including his article "Metropolitan Andrey and the revival of the east monastic tradition" (first published in 1926 in the "Theology" journal) (Sheptytskyi, K., 2001a; Sheptytskyi, K., 1926: 150163), message of Hegumen Klymentiy to the Studite monasteries in Polesia (October 16, 1931) (Sheptytskyi, K., 20016: 22), memoirs of his contemporaries: nephews Yan Casimir Sheptytsky, son of Alexander (2001: 22-25), Yan Leon Sylvester Sheptytsky, son of Leon (2001: 27-30), Elizabeth (of Sheptytsky) Vaiman, daughter of Leon (2001: 36-37), Teresa Maria Sophia Sheptytska, daughter of Alexander (2001: 45-46), and Vanda Mariia Yadviha Sheptytska, daughter of Leon (2001: 35), son of the Jewish rabbi Ezikiil, Kurt Levin (2001) saved from German repressions, witnesses Julia Sanotska (2001: 52), Ivan Kryvutskyi (2001: 73-75), Roman Novosad (2001: 76-79), as well as essays by researchers Nadiya Pikulyk (2001) and Lubomyr Senyk (2002: 2-11). These thematic collections became a significant basis for continuation of scientific research on the activities of Fr. Klymentiy. To popularize the cult of the Blessed among the believers of the UGCC, hieromonk Makariy Dutka prepared a generalizing journalistic essay "The Life of the Blessed Martyr Klymentiy Sheptytsky" (2008: 12-13).

At the same time, there has been an expansion and a certain differentiation of the topics of research on the figure of Blessed Klymentiy, among which the following thematic directions can be distinguished: correspondence of Fr. Klymentiy Sheptytsky with Fr. Tyt Wojnarowskyj in 1914-1916 (Shevchenko, 2009); participation of Hegumen Klymentiy in the development of the Univ Lavra and the network of monasteries of the Studite Rite in the 1920s-1930s, organization of activities in hiding as a result of persecution by the Soviet authorities (Dachkevych, 2006: 165-182; Kolbasin 2009; Pyshkovych, 2005: 74-113; Pyshkovych, 2017: 139-160); participation in the foundation of monasteries in Polesia and Podlachia and the development of socio-cultural work of the monks of the Studite Rite (Voitiuk, 2008; Voitiuk, 2013; Dymyd, 2017); participation in ensuring the development of the book collection of the monastery "Studion" (Kryvenko, 2006; Kryvenko, 2008); support for press publications of the Univ Lavra (Tereshchuk, 2019); preparation of the normative document "Typikon" for Studites in the context of the Eastern monastic tradition (Martynyuk, 2007: 7-35; Martynyuk, 2008: 41-58) and the norms of the Code of Canons of the Eastern Churches (Martynyuk, 2010); together with Metropolitan Andrey; interest and practical participation in the ecumenical initiatives of Metropolitan Andrey - from the Velehrad Congreses to the establishment of the Rutsky Institute and the appointment of the Exarch of Russia and Siberia (Babiak, 2009: 738; Lentsyk, 2010: 156-157; Huzar, 2015); participation in the rescue operation of Jews during the German occupation (Skira, 2017); Archimandrite Klymentiy's participation in the attempt to regulate relations with the Soviet authorities and the specifics of repression against him by the Soviet state security agencies (Hurkina, 2010; Kleban, 2015). Such a wide range of scientific research on the history of monasticism of the Studite Rite and the role of its Archimandrite, based on a huge base of sources, contributed to the popularization of the "cult of personality" in the scientific and social environment, gradual integration of newly discovered scientific facts about Klymentiy Sheptytsky in monographs and generalizing works of researchers of the history of the UGCC (Marchuk, 2004; Kyiak, 2006; Bystrytska, 2009; Pylypiv, 2011, Hentosh, 2015) and the history of religion in Ukraine (Yarotskyi, 2001: 407, 456-457).

However, it should be noted that in domestic historiography until then, the emphasis on the activities of Fr. Klymentiy Sheptytsky as a monk, Hegumen and Archimandrite of the Studites, his arrest and exile in the context of the history of the UGCC and the socio-political life of Galicia (1911-1951) prevailed, meanwhile, the secular period of his life from childhood to entering the monastery (1869-1911) remained little known. The requests of the scientific and church community for a more complete and objective reconstruction of the biography of Klymentiy Sheptytsky were, in the end, realized in the works of historians Victoria Chornopyska and Ivan Matkovskyi.

In the process of preparation of the dissertation (2013) $\mathrm{V}$. Chornopyska had gradually covered some aspects of the activity of Blessed Klymentiy Sheptytsky in the articles, in particular his role in the formation and development of the network of monasteries of the Studite Rite in 19121939 (2009); activity of the Hegumen of the Studites during the German occupation in 1941-1944 (2010a) and during the repressions and liquidation of the UGCC in 1945-1947 (20106), the innovative ideology of the development of Studite monasticism by Fr. Klymentiy (2012a), the last period of the Archimandrite's life (1947-1951) (20126). In V. Chornopyska's monograph, based on the analysis of a significant number of sources (from archival to published) and historiography, she described the main stages of 
Casimir Sheptytsky's worldview formation, identified the factors influencing his monastic vocation, and investigated the influence of Archimandrite Klymentiy's creative heritage on the spiritual development of the monasticism of the Studite Rite, traced the dynamics of the development of monasteries and showed the role of Klymentiy Sheptytsky in the development of the centers of the Studite Rite, studied the last period of the life of Klymentiy (1946-1951) from liquidation of the UGCC to death in exile (2014: 1112). Developing scientific research, V. Chornopyska continued to study the role of Metropolitan Andrey Sheptytsky in the restoration of Studite monasticism (20176), showed the role of Fr. Klymentiy in the preservation of the GCC during the period of confessional and religious transformations (2017a).

The scientist Ivan Matkovskyi, one of the employees of the Postulation Center of monasteries of the Studite Rite of the UGCC (PTsMSU) and popularizers of the memories of the Sheptytsky family, first conducted significant source work and together with Fr. Justin (Yuriy) Boiko published the correspondence of Klymentiy with his brother Stanislav and the Sheptytsky family discovered in archives of the "Studion" in Rome (Matkovskyi, Boiko, 2017), and then prepared a thorough monograph - the biography of Casimir Count Sheptytsky / Hegumen Fr. Klymentiy Sheptytsky (Matkovskyi, 2019).

Disproving "myths" about the stay of Fr. Klymentiy "all life in the shadow of the brother Metropolitan" and disproportions in historiography with an emphasis on the "monastic" period of life, the researcher set a goal to reflect the complete biography of Count Casimir - Hegumen Klymentiy Sheptytsky (Matkovskyi, 2019: 12-13). To do this, I. Matkovskyi used the most of the available sources: the correspondence of Casimir (Klymentiy) with his family, manuscript "29 years of life of Sophia of Fredro Sheptytska (18561884)..." and a collection of letters of Sophia Sheptytska in three volumes, series of publications "Historical and canonical sources of Studite monasticism in Ukraine" ("Typikon" and a collection of works by Archimandrite Klymentiy) prepared by PTsMSU, copies of individual documents from the funds of TsDIAL, materials of the declassified criminal case from the GDA SBU, the minutes of meetings of the parliament of the Austro-Hungarian Empire, periodicals of Lviv, Krakow and Vienna, newspaper of Galician Forest Company "Sylvan" ("Sylwan"), documents of Soviet government security agencies published by Serhiichuk V., as well as studies by jerm. S. Dmytrukh, V. Chornopyska, S. Hurkina, Yu. Skira, L. Kleban, who, as the researcher noted, "became the first in the study of the biography of Blessed Fr. Klymentiy" (Matkovskyi, 2019: 13-15).

In 18 chapters of the monograph, I. Matkovskyi studied the genealogical tree of the Sheptytsky family in chronological order, suggested its derivation from the DragoSas family, and showed the genealogy of his parents, Yan Kanty and Sofia of the Fredro Sheptytsky family (Chapter 1); described in detail the early childhood of Casimir, his upbringing in the family (Chapter 2), school years in the gymnasium of St. Anne in Krakow (Chapter 3); he divided his studies at the university into two periods - beginning in Krakow at the Jagiellonian University (Chapter 4) and a short period of study at the universities of Munich and Paris, obtaining the degree of "doctor of both laws" (Chapter 5); described the economic and social activities of Count Casimir in the estate in Devyatniki (Chapter 6), the political activities of the Ambassador of the Parliament of AustriaHungary (Chapters 7-8), the public activities of the Head of the Forest Society and a member of the Household Society of Galicia (Chapter 9); described the choice of monastic status, training in the novitiate (Benedictine and Studite), ordination and schema of Fr. Klymentiy in the Studite monastery (Chapter 10), the active work of the Hegumen of the Univ Lavra for the revival of Eastern monasticism (Chapter 11), the founding of monasteries in the 1920s and 1930s in Lviv, Zarvanytsia, Korostiv, Polesia and Podlachia, in Dora (Chapter 12), daily care for brother Metropolitan Andrey affected by the disease and active admonitive-organizational work (messages, instructions, orders, "General Typikon") for the monastic community of Studites (Chapter 13); nomination and activities of the Apostolic Exarch of Russia and Siberia (Chapter 14); an action to rescue Jews in Galicia during the German occupation (Chapter 15); the activities as the Archimandrite of Studites and the leader of the Church in the underground, his arrest, exile and death (Chapter 16) (Matkovskyi, 2019: 12-611). Finally, the researcher adds the memories of relatives and contemporaries of Fr. Klymentiy (Chapter 17) (Matkovskyi, 2019: 612-644).

One of the researchers of the biography of Blessed Klymentiy Sheptytsky is the prior of St. John's Lavra of the Studite Rite Fr. Justin (Yuriy) Boiko. He took an active part in finding sources and preparing for publication a series of collections of documents - letters to brother Stanislav and family, a collection of works by Fr. Klymentiy (Boiko, 2014), and then prepared the work "Spiritual fatherhood on the example of the life and work of Klymentiy Sheptytsky" (Boiko, 2018). Arranging the theological heritage of Fr. Klymentiy Sheptytsky, jerm. Yu. Boiko divided it conditionally into three thematic parts: the first part consists of messages to the monks of the Univ Lavra and filial monasteries; the second - of reports, articles and speeches published in the journals "Niva" and "Theology", and the third - of orders and documents on the organization of monastic daily life (Boiko, 2014: 10-11). Popularizing the personality of Blessed Klymentiy, Fr. Yu. Boiko drew attention to one of the interesting pages of his biography the probable secret ordination of Fr. Klymentiy as a bishop in 1939 (Boiko, 2019).

An important forum for the discussion of current issues of research and popularization of the figure of the Blessed was the International Scientific Conference "Father Klymentiy Sheptytsky (1869-1951): the life and spiritual path of the blessed Catholic Church", held on November 1516, 2019 with the participation of famous domestic and foreign researchers I. Matkovskyi, Yu. Boiko, V. Chornopyska, S. Stempen, R. Bubryak, M. Kryvenko and others (Lvivska natsionalna naukova biblioteka.., 2019).

\section{Conclusions}

Summarizing the historiographical analysis of the study of the figure of Casimir / Fr. Klymentiy Count Sheptytsky in contemporary domestic historiography, it should be noted that the results of a study of activities of Klymentiy Sheptytsky by domestic historians allowed to form a comprehensive view of the main stages of his biography. At the same time, certain aspects of his biography require additional studies. Among this aspects are the influence of Fr. Henryk Jackowski SJ on the formation of Klymentiy Sheptytsky's spiritual vocation, socio-political views of Casimir Sheptytsky as a Catholic conservative, features of the transformation of national identity from Polish to Ruthenian / Ukrainian (in comparison with his brother Metropolitan Andrey), the activities of Fr. Klymentiy Sheptytsky as the Exarch of Great Russia and Siberia, the probability of his episcopal ordination, finally, finding the tomb of the Blessed in the territory of the final resting place. 


\section{REFERENCES}

[Sheptytskyi, Klymentii]. (2001б). Poslannia o. Klymentiia ihumena Sviatouspenskoi Lavry v Unevi dlia monastyriv na Polissi (16.10.1931). Arkhymandryt Klymentii Sheptytskyi: Tematychnyi zbirnyk Sviatopokrovskoho zhinochoho monastyria Studytskoho Ustavu. Vyp. 6. S. 22. (in Ukrainian).

Amman, A. \& Stek, M. (1955). Chentsi Studytskoho Ustavu. Edmonton, Kanada: Biblioteka Katolytskoi Aktsii. 36 s. (in Ukrainian).

Arkhymandryt Klymentii (Sheptytskyi): tematychnyi zbirnyk Sviatopokrovskoho zhinochoho monastyria Studiiskoho ustavu. (2002). Univ: Sviatounivska Lavra. (in Ukrainian).

Arkhymandryt Klymentii Sheptytskyi: tematychnyi zbirnyk Sviatopokrovskoho zhinochoho monastyria Studiiskoho ustavu. (2001a). Lviv. Vyp. 6. (in Ukrainian).

Arkhymandryt Klymentii Sheptytskyi: tematychnyi zbirnyk Sviatopokrovskoho zhinochoho monastyria Studiiskoho ustavu. (20016). Lviv. Vyp. 9. (in Ukrainian).

Babiak A. (Ed.). (2000). Protokoly zasidan Lvivskykh Arkhyieparkhialnykh soboriv 1940-1944 rr. Protokoly zasidan pidhotovchykh ta urochystykh sesii. Lviv. $444 \mathrm{~s}$. (in Ukrainian).

Babiak, A. (2002). Novi ukrainski muchenyky XX st. Rym: Vydannia UKU im. sv. Klymentiia Papy. 200 s. (in Ukrainian).

Babiak, A. (2009). Uchast i rol Katolytskoi Tserkvy u Velehradskykh konhresakh (1907-1936). Narodoznavchi zoshyty. Vyp. 5-6. S. 729-742. (in Ukrainian).

Boiko, Yu. (2018). Dukhovne ottsivstvo na prykladi zhyttia ta tvorchosti Klymentiia Sheptytskoho: mahisterska robota / VNZ "Ukrainskyi Katolytskyi universytet", Lvivska dukhovna seminariia Sviatoho Dukha. Lviv. $83 \mathrm{~s}$. (in Ukrainian).

Boiko, Yu. (2019, October 09). Chy buv otets Klymentii yepyskopom: vidnaideno arkhivni dokumenty. Informatsiinyi resurs UHKTs. Retrieved from: http://ugcc.ua/articles/chi buv otets kliment$\% \mathrm{D} 1 \% 96 y$ ssheptitskiy_iepiskopom_v\%D1\%96dnaydeno_arh\%D1\%96vn\%D1\%96_dokumenti_87541.html. (in Ukrainian).

Boiko, Yu. (uporiad.). (2014). Blazhennyi prepodobnomuchenyk Klymentii (Sheptytskyi). Zbirka tvoriv. Lviv: Koleso. $225 \mathrm{~s}$. (Seriia "Istorychno-kanonichni dzherela Studiiskoho chernetstva v Ukraini", tom 2). (in Ukrainian).

Bystrytska, E. (2009). Skhidna polityka Vatykanu u konteksti vidnosyn Sviatoho Prestolu z Rosiieiu ta SRSR (1878-1964 rr.). Ternopil: Pidruchnyky i posibnyky. 416 s. (in Ukrainian).

Chornopyska V. Z. (2017a). Rol mytropolyta Andreia Sheptytskoho u vidnovlenni Studiiskoho chernetstva. Mistseva vlada y samovriaduvannia $v$ Ukraini ta derzhavakh svitu: istoriia ta suchasnist (aspekty prava). Na vshanuvannia pamiati prof. Yuriia Paneika: materialy Shostoi Vseukrainskoi naukovoteoretychnoi Internet-konferentsii. Vyp. 6 / INPP NU "Lvivska politekhnika". Lviv : Liha-Pres, 2017. S. 149-153. (in Ukrainian).

Chornopyska, V. (2009). Klymentii Sheptytskyi i studytski monastyri yak oseredky hromadsko-kulturnoho zhyttia Skhidnoi Halychyny (1912-1939). Chasopys ukrainskoi istorii. Kyiv, 2009. Vyp. 18. S. 37-43. (in Ukrainian).

Chornopyska, V. (2010a). Diialnist Klymentiia Sheptytskoho v period nimetskoi okupatsii (1941-1944 rr.). Volynski istorychni zapysky: zbirnyk naukovykh prats / vidp. red. S. M. Mishchuk. Zhytomyr: Vyd-vo ZhDU im. I. Franka. T. 5. S. 250-255. (in Ukrainian).

Chornopyska, V. (2014). Relihiina ta hromadska diialnist blazhennoho prepodobnomuchenyka Klymentiia (Sheptytskoho) (1869-1951 rr.). Lviv: Halytska vydavnycha spilka. 304 s. (in Ukrainian).

Chornopyska, V. (2017б). Rol K. Sheptytskoho v rozviazanni tserkovno-relihiinykh problem Skhidnoi Halychyny u period konfesiino-relhiinykh transformatsii (1944-1946 rr.). Visnyk Natsionanoho universytetu "Lvivska politekhinka". Seriia: yurydychni nauky. Lviv. № 876. S. 32-39. DOI: https://doi.org/10.23939/law2017.876.032. (in Ukrainian).

Chornopyska, V. Z. (20106). Tserkovno-relihiinyi kompleks UHKTs pid kerivnytstvom K. Sheptytskoho $v$ period ruinuvannia (druha polovyna 40-kh rr. KhKh st.). Naukovi zapysky Ternopilskoho natsionalnoho pedahohichnoho universytetu imeni Volodymyra Hnatiuka. Seriia: istoriia. Ternopil. Vyp. 1. S. 141-146. (in Ukrainian).

Chornopyska, V. Z. (2012a). Novatorska ideolohiia Klymentiia Sheptytskoho u rozvytku studytskykh monastyriv u Skhidnii Halychyni (20-30 rr. khkh st.). Zbirnyk naukovykh prats. Khark. nats. ped. un-t imeni $H$. S. Skovorody. Ser.: "Istoriia ta heohrafiia". Kharkiv. Vyp. 43. S. 8-15. (in Ukrainian). (in Ukrainian).

Chornopyska, V. Z. (20126). Ostannii period zhyttia arkhimandryta Klymentiia Sheptytskoho (1947-1951 rr.). Chornomorskyi litopys. Mykolaiv: Vyd-vo ChDU im. Petra Mohyly, 2012. Vyp. 6. S. 47-52. (in Ukrainian).

Chornopyska, V. Z. (2013). Relihiina ta hromadska diialnist Klymentiia Sheptytskoho (1869-1951 rr.): avtoref. dys. kand. ist. nauk: 07.00.01. / Ternopilskyi nats. ped. un-t im. V. Hnatiuka. Ternopil. $25 \mathrm{~s}$. (in Ukrainian).

Dachkevych, Y. (2006). Sviatyi Teodor, ispovidnyk, ihumen studytskyi, i monastyri studytskoho ustavu v Ukraini. Lviv: Vydvo "Svichado". 185 s. (in Ukrainian).

Danylenko, S. T. (1970). Dorohoiu hanby i zrady (pro zlochynnu diialnist uniatskoi tserkvy). Istorychna khronika. 2-e vyd. K.: Nauk. dumka. 360 s. (in Ukrainian).

Dmytruk, K. E. (1988). Unyatskye krestonostsy: vchera y sehodnia. Moskva. 381 s. (in Russian).

Dmytrukh, S. (1997). Dukhovne formuvannia monakha studyta u svitli pysan o. Klymentiia Sheptytskoho. Lviv: Svichado. $62 \mathrm{~s}$. (in Ukrainian).

Dmytrukh, S. (2002). Blazhennyi Klymentii Sheptytskyi pro molytvu u vidrodzhenykh monastyriakh Studiiskoho Ustavu. Lviv: Svichado. 132 s. (in Ukrainian).

Dutka, M. (uporiad.). (2008). Zhyttia blazhennoho sviashchennomuchenyka Klymentiia Sheptytskoho. Univskyi prochanyn. № 1. S. 12-13. (in Ukrainian).

Dymyd, M. (2017). Bachennia yednosti Tserkvy ihumenom Klymentiiem Univskym. Dodatok 1: pravylnyk misinykh stanyts; Dodatok 2: Zvit brativ Studytiv $z$ yikhnoi pratsi na uniinykh parokhiiakh Polissia i Pidliashshia. Metron. Vol. 14. S. 9-58. (in Ukrainian).

Gudziak, B. (2000). Instytut istorii Tserkvy Lvivskoi Bohoslovskoi Akademii. Kovcheh: Naukovyi zbirnyk iz tserkovnoi istorii. Lviv. Ch. 2. S. 3-14. (in Ukrainian).

Haikovskyi, M. I. (uporiad.). (2006). Khresnoiu dorohoiu. Funktsionuvannia i sproby likvidatsii Ukrainskoi Hreko-Katolytskoi Tserkvy v umovakh SRSR u 1939-1941 ta 1944-1946 rokakh: zbirnyk dokumentiv i materialiv. Lviv: Misioner. $650 \mathrm{~s}$. (in Ukrainian).

Hentosh, L. (2015). Mytropolyt Sheptytskyi: 1923-1939. Vyprobuvannia idealiv. Lviv: VNTL-Klasyka. $596 \mathrm{~s}$. (in Ukrainian).

Hordynskyi, V. (1983). Spohady pro o. Yoana Petersa, ottsiv studytiv i brativ Sheptytskykh. Svitylnyk istyny: dzherela do istorii Ukrainskoi katolytskoi bohoslovskoi akademii u Lvovi 1928-1929-1944 / red. P. Senytsia. Toronto. Ch. III. C. 463468. (in Ukrainian).

Hrynchyshyn, M. (1983). Prychynok do martyrolohii Ukrainskoi Tserkvy. Svitylnyk istyny: dzherela do istorii Ukrainskoi katolytskoi bohoslovskoi akademii u Lvovi 1928-1929-1944 / red. P. Senytsia. Toronto. Ch. III. C. 471-475. (in Ukrainian).

Hrytsyna, K. (1994, serpnia 27). Opikun ubohykh. Halytskyi shliakh. Lviv. S. 3, 5. (in Ukrainian).

Hurkina, S. (2010). Arkhymandryt Klymentii Sheptytskyi u 19441947 rr. Storinky voiennoi istorii Ukrainy: zb. nauk. st. Kyiv. Vyp. 13. S. 341-353. (in Ukrainian).

Huzar, L. (2015). Andrei Sheptytskyi, Mytropolyt Halytskyi, (19011944) - provisnyk ekumenizmu. Zhovkva: Misioner. 495 s. (in Ukrainian).

Kleban, L. (2015). Otets arkhimandryt Klymentii Sheptytskyi i radianska vlada: vidnosyny pislia smerti mytropolyta Andreia (na osnovi drukovanykh dokumentiv radianskykh spetssluzhb). Visnyk Lvivskoi komertsiinoi akademii. Vyp. 13. S. 106-114. (in Ukrainian). 
Kolbasin, V. (2009). Nebo na zemli: Palomnytstvo do Sviatouspenskoi Univskoi Lavry. Lviv: Svichado. 312 s. (in Ukrainian).

Korolevskyi, K. (2014). Mytropolyt Andrei Sheptytskyi (1865-1944) / Perekl. z frants. Ya. Kravets. Lviv: Svichado. 490 s. (in Ukrainian).

Korolevskiy, K. (1964). Metropolite Andre Szeptickyiy (1865-1944). Rome. 429 c. (Pratsi UBNT. T. XVI-XVII). (in French).

Kryvenko, M. (2006). Istoriia knyhozbirni "Studionu": movoiu dokumentiv i pohadiv. Bibliotechnyi visnyk: Naukovo-teoretychnyi i praktychnyi zhurnal. Kyiv: NBUV. № 01. S. 34-39. (in Ukrainian).

Kryvenko, M. (2008). "Litopys monastyria sviashchennomuchenyka Yosafata Studiiskoho Ustavu u Lvovi" yak dzherelo do vyvchennia istorii knyhozbirni "Studionu" (1909-1940). Zapysky Lvivskoi natsionalnoi naukovoi biblioteky Ukrainy imeni V. Stefanyka. № 1. S. 459-478. Retrieved from: http:// nbuv.gov.ua/UJRN/Innbyivs_2008_1_29. (in Ukrainian).

Kryvutskyi, I. Zustrich z ottsem arkhymandrytom Klymentiiem Sheptytskym. Arkhymandryt Klymentii (Sheptytskyi): tematychnyi zbirnyk Sviatopokrovskoho zhinochoho monastyria Studiiskoho Ustavu. Lviv, 2001. Vyp. 9. S. 73-75. (in Ukrainian).

Kyiak, S. (2006). Identychnist ukrainskoho katolytsyzmu: henezys, problemy, perspektyvy. Ivano-Frankivsk: Nova Zoria. $632 \mathrm{~s}$. (in Ukrainian).

Kyrychuk, L. (1995, veresnia 10). Kazymyr Sheptytskyi - malodoslidzhena zasluzhena postat v zhytti UKTs. Meta. S. 16-17. (in Ukrainian).

Labinska K. (2006). Sviatets iz Uneva. Nauka i suspilstvo: shchomisiachnyi naukovo-populiarnyi i literaturno-khudozhnii iliustrovanyi zhurnal. Kyiv. № 7-8. S. 30-32. (in Ukrainian).

Labinska, K. (1999, lystopad 19) Sviatets iz Uneva. Meta. Lviv. S. 2. (in Ukrainian).

Lentsyk, V. (1984). Sheptytskyi Klymentii Kazymyr (1864-1950). Entsyklopediia ukrainoznavstva. Slovnykova chastyna / hol. red. V. Kubiiovych. T. 10. Paryzh; Niu-York. S. 3845. (in Ukrainian).

Lentsyk, V. (2010). Vyznachni postati Ukrainskoi Tserkvy: mytropolyt Andrei Sheptytskyi i Patriiarkh Yosyf Slipyi. Lviv: Svichado. 608 s. (in Ukrainian).

Levin. K. (2001). Ihumen Klymentii Sheptytskyi. Arkhymandryt Klymentii (Sheptytskyi): tematychnyi zbirnyk Sviatopokrovskoho zhinochoho monastyria Studiiskoho Ustavu. Lviv. Vyp. 9. (in Ukrainian).

Lvivska natsionalna naukova biblioteka Ukrainy imeni V. Stefanyka; Postuliatsiinyi Tsentr Monastyriv Studiiskoho Ustavu UHKTs. (2019). Mizhnarodna naukova konferentsiia "Otets Klymentii Sheptytskyi (1869-1951): zhyttievyi i dukhovnyi shliakh Blazhennoho Katolytskoi Tserkvy" (Lviv, 15-16 lystopada 2019 r.): Prohrama. Lviv. $14 \mathrm{~s}$. (in Ukrainian).

Marchuk, V. (2004). Tserkva, dukhovnist, natsiia: Ukrainska hreko-katolytska tserkva v suspilnomu zhytti Ukrainy XX st. Ivano-Frankivsk: Plai. 464 s. (in Ukrainian).

Martyniuk, T. (2007). Mytropolyt Andrei ta blazhennyi Klymentii Sheptytski yak zakonodavtsi vidrodzhenoho studiiskoho chernetstva. Typikony / red. kol.: yerm. Venedykt (Valerii Aleksiichuk) ta in. Lviv : Svichado. S.7-35. (in Ukrainian).

Martyniuk, T. (2008). Vidnovlennia studiiskoho chernetstva sluhoiu Bozhym mytropolytom Andreiem i blazh. svshchmuch. Klymentiiem. Studiiske monashestvo: Materialy konferentsii. Lviv: Svichado, 2008. S. 41-58. (in Ukrainian).

Martynyuk, T.-T. (2010). Caratteristica giuridica dei gradi della consacrazione monastica. II Tipico generale dei monastery studiti nel contesto della tradizione monastica e ded CCEO. Dissertatio ad doctoratum (Pontificium Institutum Orientale. Facultas luris Canonici Orientalis). Leopolis [Lviv, Ukraine]. 311 p. (in Italian).

Marushchak, M. (1995). "Vynnym sebe ne vyznaiu". Meta. №18. S. 5-11. (in Ukrainian).

Marusyn, M. (1995). Monashyi Ustav sv. Teodora Studyta na Ukraini. Rym: Vydannia Ukrainskoho Katolytskoho universytetu

ISSN 1728-9343 (Print)

ISSN 2411-3093 (Online) sv. Kymenta Papy. 88 s. (Pratsi Hreko-Katolytskoi Bohoslovskoi Akademii, t. 82). (in Ukrainian).

Matkovskyi, I. \& Boiko, Yu. (Ed.). (2017). Blazhennyi arkhimandryt Klymentii (Kazymyr hraf Sheptytskyi). Lysty do ridnoho brata Stanislava hrafa Sheptytskoho ta rodyny / per. z pol. I. Matkovskoho. Lviv. 224 s. (in Ukrainian).

Matkovskyi, I. (2019). Kazymyr hraf Sheptytskyi - otets Klymentii: polskyi arystokrat, ukrainskyi iieromonakh, ekzarkh Rosii ta Sybiru, arkhimandryt Studytiv, Pravednyk narodiv svitu, blazhennyi Katolytskoi Tserkvy. Lviv. 664 s. (in Ukrainian).

Mytsko, I. (1998). Sviatouspenska Lavra v Unevi (kinets XIII st. kinets $X X$ st.). Lviv: Svichado. $328 \mathrm{~s}$. (in Ukrainian).

Novosad, R. (2001). Zustrich i spilne perebuvannia z arkhimandrytom Klymentiiem Sheptytskym v kameri vnutrishnoi tiurmy MHB u Kyievi v 1948 r. Arkhymandryt Klymentii (Sheptytskyi): tematychnyi zbirnyk Sviatopokrovskoho zhinochoho monastyria Studiiskoho Ustavu. Lviv. Vyp. 9. S. 76-79. (in Ukrainian).

Parashchak, I. (1994, chervnia 30). Khto vstane zo mnoiu navproty zlochyntsiv? (Ps. 94: 16). Za vilnu Ukrainu. S. 5-6. (in Ukrainian).

Pikulyk, N. (2001). "I vin uziav svii khrest". Arkhymandryt Klymentii (Sheptytskyi): tematychnyi zbirnyk Sviatopokrovskoho zhinochoho monastyria Studiiskoho Ustavu. Lviv. Vyp. 9. (in Ukrainian).

Pikulyk, N., Senyk, L. (1997). Klymentii Sheptytskyi - sluha Bozhyi. Lviv: Svichado. $66 \mathrm{~s}$. (in Ukrainian).

Prylip, O., Martyniuk, T. (1998). Monakhy-studyty na Hutsulshchyni: Rozdumy nad istoriieiu odnoho monastyria. Lviv: Svichado. 71 s. (in Ukrainian).

Pylypiv, I. V. (2011). Hreko-katolytska tserkva v suspilno-politychnomu zhytti Skhidnoi Halychyny (1918-1939 rr.). Ternopil: Ekonomichna dumka TNEU. 440 s. (in Ukrainian).

Pyshkovych, M. (2005). Istoriia Sviato-Uspenskoi Univskoi Lavry ta studiiskoho monashestva. Lviv: Svichado. 172 s. (in Ukrainian).

Pyshkovych, M. (2017). Istoriia studiiskoho chernetstva Ukrainskoi Hreko-Katolytskoi Tserkvy u 1950-1990 rokakh. Acta studiosa: Bohoslovskyi naukovyi zbirnyk. Lviv: Vydavnytstvo UKU. Ch. 9. S. 139-160. (in Ukrainian).

Saiko, O. (2000). Blazhennyi sviashchennomuchenyk Klymentii Sheptytskyi. UHKTs s. Prylbychi. Retrieved from: https://prylbychi-ugcc.at.ua/load/pro_blazhennogo_klimentija/statti_v_interneti/blazhennij_svjashhennomuchenik_klimentijsheptickij/11-1-0-16. (in Ukrainian).

Sanotska, Yu. (2001). Vidvidyny Florynky. Arkhymandryt Klymentii (Sheptytskyi): tematychnyi zbirnyk Sviatopokrovskoho zhinochoho monastyria Studiiskoho Ustavu. Lviv. Vyp. 9. S. 52. (in Ukrainian).

Senyk, L. (2002). U svitli khrystyianskoi pravdy, dobra, liubovi. Arkhymandryt Klymentii (Sheptytskyi). Tematychnyi zbirnyk Sviatopokrovskoho zhinochoho monastyria Studiiskoho Ustavu. Univ: Sviatounivska Lavra. S. 2-11. (in Ukrainian).

Senytsia, P. (Ed.). (1983). Svitylnyk istyny: dzherela do istorii Ukrainskoi katolytskoi bohoslovskoi akademii u Lvovi 19281929-1944: v 3-kh tt. Toronto; Chykaho: Vydannia Ukrainskoho Katolytskoho Universytetu im. sv. Klymenta Papy. T. 3. 960 s. (in Ukrainian).

Senytsia, P. (hol. red.). (1973). Svitylnyk istyny: dzherela do istorii Ukrainskoi katolytskoi bohoslovskoi akademii u Lvovi 19281929-1944: v 3-kh tt. Toronto; Chykaho: Vydannia Ukrainskoho Katolytskoho Universytetu im. sv. Klymenta Papy. T. 1. 719 s.; T. 2. $663 \mathrm{~s}$. (in Ukrainian).

Serhiichuk V. (Ed.). (2006). Likvidatsiia UHKTs (1939-1946). Dokumenty radianskykh orhaniv derzhavnoi bezpeky: [u 2-kh t.]. K.: PP Serhiichuk M.I. T. 1. 920 s.; T. 2. 804 s. (in Ukrainian).

Serhiichuk, V. (Ed.). (1997). Hreko-katolytska tserkva v 1944$1991 \mathrm{rr}$. Ukrainskyi istorychnyi zhurnal. № 2. S. 98-110. (in Ukrainian).

SKHID No. 2 (166) March-April 2020 
Serhiichuk, V. (Ed.). (2001). Neskorena Tserkva: Podvyzhnytstvo hreko-katolykiv Ukrainy v borotbi za viru i derzhavu. K.: Dnipro. 496 s. (in Ukrainian)

Serhiichuk, V. (red.). (2005). Mytropolyt Andrei Sheptytskyi u dokumentakh radianskykh orhaniv derzhavnoi bezpeky (19391944 rr.). K.: Ukrainska Vydavnycha Spilka. 480 s. (in Ukrainian).

Sheptytska, Tereza. (2001). Spohady pro ottsia Klymentiia, studyta, Kazymyra Sheptytskoho. Arkhymandryt Klymentii (Sheptytskyi): tematychnyi zbirnyk Sviatopokrovskoho zhinochoho monastyria Studiiskoho Ustavu. Lviv. Vyp. 9. S. 45-46. (in Ukrainian).

Sheptytska, Vanda Mariia Yadviha. (2001). Spohady pro ottsia Klymentiia (Kazymyra Sheptytskoho). Arkhymandryt Klymentil (Sheptytskyi): Tematychnyi zbirnyk Sviato-pokrovskoho zhinochoho monastyria Studiiskoho Ustavu. Vyp. 9. Lviv. Vyp. 9. S. 35. (in Ukrainian)

Sheptytskyi, Ivan Lev. (1983). Otets Klymentii - arkhymandryt Studytiv. Svitylnyk istyny: dzherela do istorii Ukrainskoi katolytskoi bohoslovskoi akademii u Lvovi 1928-1929-1944 / red. P. Synytsia. Toronto-Chykaho. Ch. III. S. 776-782. (in Ukrainian).

Sheptytskyi, Klymentii. (1926). Mytropolyt Andrei i obnovlennia Skhidnoi chernechoi tradytsii. Bohosloviia. T. 4. Kn. 1-4. S. 150-163. (in Ukrainian)

Sheptytskyi, Klymentii. (2001a). Mytropolyt Andrei i obnovlennia skhidnoi chernechoi tradytsii. Arkhymandryt Klymentii Sheptytskyi: Tematychnyi zbirnyk Sviatopokrovskoho zhinochoho monastyria Studiiskoho ustavu, vyp. 6, Lviv. (in Ukrainian).

Sheptytskyi, Ya. K. (1996). Otets Klymentii Sheptytskyi. Zhyttiepys na pidstavi arkhivnykh materialiv rodyny Sheptytskykh / perekl. z pol. Nadii Pikulyk, Liubomyra Senyka; perkl. z frants. Zhinet Maksymovych. Lviv : Svichado. 93 s. (in Ukrainian).

Sheptytskyi, Ya. K. (2016). Otets Klymentii Sheptytskyi: zhyttiepys na pidstavi arkhivnykh materialiv rodyny Sheptytskykh. Lviv: Svichado. 112 s. (in Ukrainian).

Sheptytskyi, Yan Kazymyr. (2001). Moi spohady pro Kazymyra Sheptytskoho - ottsia Klymentiia Sheptytskoho. Arkhymandryt Klymentii (Sheptytskyi): tematychnyi zbirnyk Sviatopokrovskoho zhinochoho monastyria Studiiskoho Ustavu. Lviv. Vyp. 9. S. 22-25. (in Ukrainian).

Sheptytskyi, Yan Leon. (2001). Spohady pro stryika. Arkhymandryt Klymentii (Sheptytskyi): tematychnyi zbirnyk Sviatopokrovskoho zhinochoho monastyria Studiiskoho Ustavu. Lviv. Vyp. 9. S. 27-30. (in Ukrainian).

Shevchenko, O. V. (2009). Lystuvannia o. Klymentiia Sheptytskoho do o. Tyta Voinarovskoho (zhovten 1914 - Iypen 1916 rr.). Problemy istorii Ukrainy XIX - pochatku XX st.: Zb. nauk. pr. Kyiv. Vyp. XVI. S. 430-439. (in Ukrainian).

Shkrabiuk, P. (1995). Vynohradnyk Hospodnii: Istoriia zhyttia o. d-ra Yosyfa Kladochnoho / In-t ukrainoznavstva im. I.Krypiakevycha NAN Ukrainy. Lviv: Misioner. $280 \mathrm{~s}$. (in Ukrainian).

Skira, Yu. R. (2017). Uchast monakhiv Studiiskoho Ustavu u poriatunku yevreiv na terytorii Lvivskoi arkhiieparkhii HrekoKatolytskoi Tserkvy u 1942-1944 rr. Dysertatsiia... kandydata istorychnykh nauk (doktora filosofii) za spetsialnistiu 07.00.01 "Istoriia Ukrainy" / Natsionalnyi universytet "Lvivska politekhnika"; Instytut ukrainoznavstva im. I. Krypiakevycha NAN Ukrainy, Lviv. 221 s. (in Ukrainian).

Tereshchuk, O. (2019). Presovi vydannia Sviato-Uspenskoi Univskoi Lavry studiiskoho Ustavu: "Yasna Put" (1935-1939 rr.) ta "Prominchyk Sontsia Liubovi" (1936-1937 rr.). Zbirnyk prats Naukovo-doslidnoho instytu presoznavstva / Lvivska natsionalna naukova biblioteka Ukrainy im. V. Stefanyka. Vyp. 9 (27). S. 63-86. DOI: https://doi.org/10.37222/2524-0331-20199(27)-5. (in Ukrainian).

Turii, O. (uporiad.). (2005). Tserkva muchenykiv / Instytut Istorii Tserkvy UKU. Lviv: Svichado. $56 \mathrm{~s}$. (in Ukrainian).

Typikon. (1996) / Mytropolyt Andrei i arkhymandryt Klymentii Sheptytski; pereklad $\mathrm{z}$ frants. iierm. Nykanor Deineha ta iierm. Yulian Voronovskyi. Lviv: Svichado. 256 s. (in Ukrainian).
Typikony. (2007) / Red. kol.: iierm. Venedykt (Valerii Aleksiichuk), iierm. Teodor (Taras Martyniuk), skhm. Irynei (Ivan Voloshyn) ta iierm. Yustyn (Yurii Boiko). Lviv: Svichado. 140 s. (in Ukrainian).

UHKTs. (2001). Beatyfikatsiia sluh Bozhykh 27 chervnia 2001 roku. Korotki biohrafii. Informatsiinyi resurs UHKTs. Retrieved from: https://web.archive.org/web/20151208151251/http:// old.ugcc.org.ua/ukr/ugcc history/martyrs/.

Vaiman, E. (2001). Zaiava. Arkhymandryt Klymentii (Sheptytskyi): tematychnyi zbirnyk Sviatopokrovskoho zhinochoho monastyria Studiiskoho Ustavu. Lviv. Vyp. 9. S. 36-37. (in Ukrainian).

Voitiuk, O. (2008). Misiini stanytsi studytskoho chernetstva na ukrainsko-polskomu pohranychchi. Ukraina: kulturna spadshchyna, natsionalna svidomist, derzhavnist. Lviv, Vyp. 17, S. 501-507. (in Ukrainian).

Voitiuk, O. M. (2013). Suspilno-kulturna diialnist monakhiv studytskoho ustavu hreko-katolytskoi tserkvy (1898-1947 rr.): avtoref. dys. kand. ist. nauk: 07.00 .01 / Inst. ukrainoznavstva im. I. Krypiakevycha NAN Ukrainy. Lviv. 19 s. (in Ukrainian).

Yarotskyi, P. (2001). Katolytsyzm. Istoriia relihii v Ukraini: u 10-ty tt. / Redkol.: A. Kolodnyi (holova) ta in. Kyiv: Ukr. Tsentr dukhovnoi kultury, 1996-2002. Kyiv: Svit znan. 598 s. (in Ukrainian).

Zinkevych, O. \& Lonchyna, T. R. (red.) (1985). Ukrainska Katolytska Tserkva: Dokumenty, materiialy, khrystyianskyi samvydav Ukrainy. Martyrolohiia Ukrainskykh Tserkov: u 4-kh tomakh. T. 2: Toronto; Baltymor: Ukrainske vydavnytstvo "Smoloskyp" im. V. Symonenka, 1985. 839 s. (in Ukrainian).

\section{LIST OF REFERENCES LINK}

Амман А., Стек М. Ченці Студитського Уставу. Едмонтон, Канада: Бібліотека Католицької Акції, 1955. 36 с.

Архимандрит Климентій (Шептицький): тематичний збірник Святопокровського жіночого монастиря Студійського уставу / Наук. ред. схм. Венедикта (Щурат-Глуха) та ін. Львів, 2001. Вип. 9.

Архимандрит Климентій (Шептицький): тематичний збірник Святопокровського жіночого монастиря Студійського уставу / Наук. ред. схм. Венедикта (Щурат-Глуха) та ін. Унів: Святоунівська Лавра, 2002.

Архимандрит Климентій Шептицький: тематичний збірник Святопокровського жіночого монастиря Студійського уставу / Наук. ред. схм. Венедикта (Щурат-Глуха) та ін. Львів, 2001. Вип. 6.

Баб'як А. (упоряд.) Протоколи засідань Львівських Архиєпархіальних соборів 1940-1944рр. Протоколи засідань підготовчих та урочистих сесій. Львів, 2000. 444 с.

Баб'як А. Нові українські мученики XX ст. Рим: Видання УкУ ім. св. Климентія Папи, 2002. 200 с.

Баб'як А. Участь і роль Католицької Церкви у Велеградських конгресах (1907-1936). Народознавчі зошити. 2009. Вип. 5-6. С. 729-742.

Бистрицька Е. Східна політика Ватикану у контексті відносин Святого Престолу з Росією та СРСР (1878-1964рр.). Тернопіль: Підручники і посібники, 2009. 416 с.

Бойко Ю. Духовне отцівство на прикладі життя та творчості Климентія Шептицького: магістерська робота / ВНЗ "Український Католицький університет", Львівська духовна семінарія Святого Духа. Львів, 2018. 83 с.

Бойко Ю. Чи був отець Климентій єпископом: віднайдено архівні документи. (09.10. 2019). URL: http://ugcc.ua/articles/ chi buv otets kliment\%D1\%96y sheptitskiy iepiskopom v\%D1\%96dnaydeno_arh\%D1\%96vn\%D1\%96_dokumenti_87541.html (дата звернення: 31.03.2020).

Бойко Ю. (упоряд.). Блаженний преподобномученик Климентій (Шептицький). Збірка творів. Львів: Колесо, 2014. 225 с. (Серія "Історично-канонічні джерела Студійського чернецтва в Україні", том 2).

Вайман Е. Заява. Архимандрит Климентій (Шептицький): тематичний збірник Святопокровського жіночого монастиря Студійського Уставу. Львів, 2001. Вип. 9. С. 36-37. 
Войтюк О. Місійні станиці студитського чернецтва на українсько-польському пограниччі. Україна: культурна спадщина, національна свідомість, державність. Львів, 2008, Вип. 17, С. 501-507.

Войтюк О. М. Суспільно-культурна діяльність монахів студитського уставу греко-католицької церкви (1898-1947рр.): автореф. дис. канд. іст. наук: 07.00.01. / Інст. українознавства ім. І. Крип'якевича НАН України. Львів, 2013. 19 с.

Гайковський М. І. (упоряд.). Хресною дорогою. Функціонування і спроби ліквідації Української Греко-Католицької Церкви в умовах СРСР у 1939-1941 та 1944-1946 роках: збірник документів і матеріалів. Львів: Місіонер, 2006. 650 с.

Гентош Л. Митрополит Шептицький: 1923-1939. Випробування ідеалів. Львів: ВНТЛ-Класика, 2015. 596 с.

Гординський В. Спогади про о. Йоана Петерса, отців студитів і братів Шептицьких. Світильник істини: джерела до історії Української католицької богословської академії у Львові 1928-1929-1944 / ред. П. Синиця. Торонто, 1983. 4. III. C. $463-468$.

Гринчишин М. Причинок до мартирології Української Церкви. Світильник істини: джерела до історії Української католицької богословської академії у Львові 1928-19291944 / ред. П. Синиця. Торонто. 1983. Ч. ІІІ. С. 471-475.

Грицина К. Опікун убогих. Галицький шлях. 27 серпня 1994. C. 3,5 .

Ґудзяк Б. Інститут історії Церкви Львівської Богословської Академії. Ковчег: Науковий збірник із церковної історії. Львів, 2000. Ч. 2. С. 3-14.

Гузар Л. Андрей Шептицький, Митрополит Галицький, (19011944) - провісник екуменізму. Жовква: Місіонер, 2015. $495 \mathrm{c}$.

Гуркіна С. Архимандрит Климентій Шептицький у 19441947 рр. Сторінки воєнної історії України: зб. наук. ст. Київ, 2010. Вип. 13. С. 341-353.

Даниленко С. Т. Дорогою ганьби і зради (про злочинну діяльність уніатської церкви). Історична хроніка. 2-е вид. К.: Наук. думка, 1970. 360 с.

Дачкевич Й. Святий Теодор, ісповідник, ігумен студитський, і монастирі студитського уставу в Україні. Львів: Вид-во "Свічадо", 2006. 185 с.

Димид М. Бачення єдності Церкви ігуменом Климентієм Унівським. Додаток 1: Правильник місйних станиць; Додаток 2: Звіт братів Студитів з їхньої праці на унійних парохіях Полісся і Підляшшя. Метрон. 2017. № 14. С. 9-58.

Дмитрук К. Е. Униатские крестоносцы: вчера и сегодня. Москва, 1988. 381 с.

Дмитрух С. Блаженний Климентій Шептицький про молитву у відроджених монастирях Студійського Уставу. Львів: Свічадо, 2002. 132 с.

Дмитрух С. Духовне формування монаха студита у світлі писань о. Климентія Шептицького. Львів: Свічадо, 1997. $62 \mathrm{c}$.

Дутка М. (упоряд.). Життя блаженного священномученика Климентія Шептицького. Унівський прочанин. 2008. №1. C. $12-13$.

Зінкевич О. і Лончина Т. Р. (ред.). Мартирологія Українських Церков: у 4-х томах. Т. 2: Українська Католицька Церква: Документи, матеріяли, християнський самвидав України. Торонто; Балтимор: Українське видавництво "Смолоскип" ім. В. Симоненка, 1985. 839 с.

Киричук Л. Казимир Шептицький - малодосліджена заслужена постать в житті УКЦ. Мета. 10 вересня 1995. С. 16-17.

Кияк С. Ідентичність українського католицизму: генезис, проблеми, перспективи. Івано-Франківськ: Нова Зоря, 2006. $632 \mathrm{c}$.

Клебан Л. Отець архімандрит Климентій Шептицький і радянська влада: відносини після смерті митрополита Андрея (на основі друкованих документів радянських спецслужб). Вісник Львівської комерційної академії. 2015. Вип. 13 C. $106-114$
Колбасін В. Небо на землі: Паломництво до Святоуспенської Унівської Лаври. Львів: Свічадо, 2009. 312 с.

Королевський К. Митрополит Андрей Шептицький (1865-1944) / Перекл. з франц. Я. Кравець. Львів: Свічадо, 2014. 490 с.

Кривенко М. "Літопис монастиря священномученика Йосафата Студійського Уставу у Львові" як джерело до вивчення історії книгозбірні "Студіону" (1909-1940). Записки Львівської національної наукової бібліотеки України імені В. Стесраника. 2008. № 1. C. 459-478. URL: http://nbuv.gov.ua/UJRN/Innbyivs_2008_1_29.

Кривенко М. Історія книгозбірні "Студіону": мовою документів і погадів. Бібліотечний вісник: Науково-теоретичний $i$ практичний журнал. Київ: НБУВ, 2006. № 01. С. 34-39.

Кривуцький І. Зустріч з отцем архимандритом Климентієм Шептицьким. Архимандрит Климентій (Шептицький): тематичний збірник Святопокровського жіночого монастиря Студійського Уставу. Львів, 2001. Вип. 9. С. 73-75.

Лабінська К. Святець із Унева. Мета. Львів, 19 листопада 1999. C. 2.

Лабінська К. Святець із Унева. Наука і суспільство: щомісячний науково-популярний $і$ літературно-художній ілюстрований журнал. Київ, 2006. № 7-8. С. 30-32.

Левін К. Ігумен Климентій Шептицький. Архимандрит Климентій (Шептицький): тематичний збірник Святопокровського жіночого монастиря Студійського Уставу. Львів, 2001. Вип. 9.

Ленцик В. Визначні постаті Української Церкви: митрополит Андрей Шептицький і Патріярх Йосифф Сліпий. Львів: Свічадо. 2010. 608 с.

Ленцик В. Шептицький Климентій Казимир (1864-1950). Енциклопедія українознавства. Словникова частина / гол. ред. В. Кубійович. Т. 10. Париж; Нью-Йорк, 1984. С. 3845.

Львівська національна наукова бібліотека України імені В. Стефаника; Постуляційний Центр Монастирів Студійського Уставу УГКЦ. Міжнародна наукова конференція "Отець Климентій Шептицький (1869-1951): життєвий і духовний шлях Блаженного Католицької Церкви" (Львів, 15-16 листопада 2019 р.): Програма. Львів, 2019. 14 с.

Мартинюк Т. Відновлення студійського чернецтва слугою Божим митрополитом Андреєм і блаж. свщмуч. Климентієм. Студійське монашество: Матеріали конфреренцій. Львів: Свічадо, 2008. С. 41-58.

Мартинюк Т. Митрополит Андрей та блаженний Климентій Шептицькі як законодавці відродженого студійського чернецтва. Типікони / ред. кол.: єрм. Венедикт (Валерій Алексійчук) та ін. Львів : Свічадо, 2007. С.7-35.

Марусин М. Монаший Устав св. Теодора Студита на Україні. Рим: Видання Українського Католицького університету св. Кимента Папи, 1995. 88 с. (Праці Греко-Католицької Богословської Академії, т. 82).

Марущак М. "Винним себе не визнаю". Мета. 1995. №18. C. $5-11$.

Марчук В. Церква, духовність, нація: Українська греко-католицька церква в суспільному житті України XX ст. ІваноФранківськ: Плай, 2004. 464 с.

Матковський I. Казимир граф Шептицький - отець Климентій: польський аристократ, український ієромонах, екзарх Росії та Сибіру, архімандрит Студитів, Праведник народів світу, блаженний Католицької Церкви. Львів. 2019. 664 с.

Матковський І., Бойко Ю. (упоряд.). Блаженний архімандрит Климентій (Казимир граф Шептицький). Листи до рідного брата Станіслава графа Шептицького та родини / пер. 3 пол. І. Матковського. Львів, 2017. 224 с.

Мицько І. Святоуспенська Лавра в Уневі (кінець XIII ст. - кінець XX ст.). Львів: Свічадо, 1998. 328 с.

Новосад Р. Зустріч і спільне перебування з архімандритом Климентієм Шептицьким в камері внутрішньої тюрми МГБ у Києві в 1948 р. Архимандрит Климентій (Шептицький): тематичний збірник Святопокровського жіночого монастиря Студійського Уставу. Львів, 2001. Вип. 9. С. 76-79. 
Паращак І. Хто встане зо мною навпроти злочинців? (Пс. 94: 16). За вільну Україну. 1994. 30 червня. С. 5-6.

Пилипів І.В. Греко-католицька церква в суспільно-політичному житті Східної Галичини (1918-1939рр.): монографрія. Тернопіль: Економічна думка ТНЕУ, 2011. 440 с.

Пишкович М. Історія Свято-Успенської Унівської Лаври та студійського монашества. Львів: Свічадо, 2005. 172 с.

Пишкович М. Історія студійського чернецтва Української Греко-Католицької Церкви у 1950-1990 роках. Acta studiosa: Богословський науковий збірник. Львів: Видавництво УКУ, 2017. Ч. 9. С. $139-160$

Пікулик Н. "I він узяв свій хрест". Архимандрит Климентій (Шептицький): тематичний збірник Святопокровського жіночого монастиря Студійського Уставу. Львів, 2001. Вип. 9.

Пікулик Н., Сеник Л. Климентій Шептицький - слуга Божий. Львів : Свічадо, 1997. 66 с.

Приліп О., Мартинюк Т. Монахи-студити на Гуцульщині: Роздуми над історією одного монастиря. Львів: Свічадо, 1998. $71 \mathrm{c}$.

Сайко О. Блаженний священномученик Климентій Шептицький. (2000). URL: https://prylbychi-ugcc.at.ua/load/pro_blazhennogo klimentija/statti v interneti/blazhennij_svjashhennomuchenik_klimentij_sheptickij/11-1-0-16. (дата звернення: 25.02 .2020 ).

Саноцька Ю. Відвідини Фльоринки. Архимандрит Климентій (Шептицький): тематичний збірник Святопокровського жіночого монастиря Студійського Уставу. Львів, 2001. Вип. 9. С. 52.

Сеник Л. У світлі християнської правди, добра, любові. Архимандрит Климентій (Шептицький). Тематичний збірник Святопокровського жіночого монастиря Студійського Уставу. Унів: Святоунівська Лавра, 2002. С. 2-11.

Сениця П. (гол. ред.). Світильник істини: джерела до історії Української католицької богословської академії у Львові 1928-1929-1944: в 3-х тт. Торонто; Чикаго: Видання Українського Католицького Університету ім. св. Климента Папи, 1973. T. 1. 719 c.; 1973, T. 2. 663 c.; 1983. T. 3. 960 c.

Сергійчук В. (ред.). Ліквідація УГКЦ (1939-1946). Документи радянських органів державної безпеки: [у 2 т.]. К.: ПП Сергійчук М.І., 2006. Т.1. 920 с.; Т.2. 804 с.

Сергійчук В. (ред.). Митрополит Андрей Шептицький у документах радянських органів державної безпеки (19391944 рр.). К.: Українська Видавнича Спілка, 2005. 480 с.

Сергійчук В. (ред.). Нескорена Церква: Подвижництво грекокатоликів України в боротьбі за віру і державу. К.: Дніпро, 2001. 496 c.

Сергійчук В. (упорядник). Греко-католицька церква в 19441991 рр. Український історичний журнал. 1997. № 2. С. 98110.

Скіра Ю. Р. Участь монахів Студійського Уставу у порятунку євреїв на території Львівської архієпархії Греко-Католицької Церкви у 1942-1944 рр. Дисертація... кандидата історичних наук (доктора філософіiі) за спеціальністю 07.00 .01 "Історія України" / Національний університет "Львівська політехніка"; Інститут українознавства ім. І. Крип'якевича НАН України, Львів, 2017. 221 с.

Терещук О. Пресові видання Свято-Успенської Унівської Лаври студійського Уставу: "Ясна Путь" (1935-1939 рр.) та "Промінчик Сонця Любові" (1936-1937рр.). Збірник праць Науково-дослідного інститу пресознавства / Львівська національна наукова бібліотека України ім. В. Стефаника. 2019. Вип. 9 (27). С. 63-86. DOI: https://doi.org/10.37222/ 2524-0331-2019-9(27)-5.

Типікон / Митрополит Андрей і архимандрит Климентій Шептицькі; переклад з франц. ієрм. Никанор Дейнега та ієрм. Юліан Вороновський. Львів: Свічадо, 1996. 256 с.

Типікони / Ред. кол.: ієрм. Венедикт (Валерій Алексійчук), ієрм. Теодор (Тарас Мартинюк), схм. Іриней (Іван Волошин) та ієрм. Юстин (Юрій Бойко). Львів: Свічадо, 2007. 140 с.

Турій О. (упоряд.). Церква мучеників / Інститут Історії Церкви УКУ. Львів: Свічадо, 2005. 56 с.
УГКЦ. Беатифікація слуг Божих 27 червня 2001 року. Короткі бiorpaфiï. (2001). URL: https://web.archive.org/web/20151208151251/http://old.ugcc.org.ua/ukr/ugcc_history/martyrs/ (дата звернення: 28.03.2020).

Чорнописька В. Діяльність Климентія Шептицького в період німецької окупації (1941-1944рр.). Волинські історичні записки: збірник наукових праць / відп. ред. С. М. Міщук. Житомир: Вид-во ЖДУ ім. І. Франка, 2010. Т. 5. С. 250255.

Чорнописька В. 3. Новаторська ідеологія Климентія Шептицького у розвитку студитських монастирів у Східній Галичині (20-30 pp. хх ст.). Збірник наукових праць. Харк. нац. пед. ун-т імені Г. С. Сковороди. Сер.: "Історія та географрія". Харків, 2012. Вип. 43. С. 8-15.

Чорнописька В. 3. Релігійна та громадська діяльність Климентія Шептицького (1869-1951рр.): автореф. дис. канд. іст. наук: 07.00.01. / Тернопільський нац. пед. ун-т ім. В. Гнатюка. Тернопіль, 2013. 25 с.

Чорнописька В. Климентій Шептицький і студитські монастирі як осередки громадсько-культурного життя Східної Галичини (1912-1939). Часопис української історії. Київ, 2009. Вип. 18. С. 37-43.

Чорнописька В. Останній період життя архімандрита Климентія Шептицького (1947-1951рр.). Чорноморський літопис. Миколаїв: Вид-во ЧДУ ім. Петра Могили, 2012. Вип. 6. C. $47-52$.

Чорнописька В. Релігійна та громадська діяльність блаженного преподобномученика Климентія (Шептицького) (18691951 рр.). Львів: Галицька видавнича спілка, 2014. 304 с.

Чорнописька В. Роль К. Шептицького в розв'язанні церковнорелігійних проблем Східної Галичини у період конфесійнорелгійних трансформацій (1944-1946рр.). Вісник Націонаьного університету "Львівська політехінка". Серія: юридичні науки. Львів, 2017. № 876. С. 32-39. DOI: https:// doi.org/https://doi.org/10.23939/law2017.876.032.

Чорнописька В. Роль митрополита Андрея Шептицького у відновленні Студійського чернецтва. Місцева влада й самоврядування в Україні та державах світу: історія та сучасність (аспекти права). На вшанування пам'яті проф. Юрія Панейка: матеріали Шостої Всеукраїнської науково-теоретичної Інтернет-конферениії. Вип. 6 / ІНПП НУ "Львівська політехніка". Львів : Ліга-Прес, 2017. C. $149-153$

Чорнописька В. Церковно-релігійний комплекс УГКЦ під керівництвом К. Шептицького в період руйнування (друга половина 40-х рр. XX ст.). Наукові записки Тернопільського національного педагогічного університету імені Володимира Гнатюка. Серія: історія. Тернопіль, 2010. Вип. 1. С. 141-146.

Шевченко О.В. Листування о. Климентія Шептицького до о. Тита Войнаровського (жовтень 1914 - липень 1916 рр.). Проблеми історії України XIX - початку XX cm.: Зб. наук. пр. Київ, 2009. Вип. XVI. С. 430-439.

Шептицька Ванда Марія Ядвіга. Спогади про отця Климентія (Казимира Шептицького). Архимандрит Климентій (Шептицький): Тематичний збірник Свято-покровського жіночого монастиря Студійського Уставу. Вип. 9. Львів, 2001. Вип. 9. С. 35

Шептицька Тереза, сестра францисканка. Спогади про отця Климентія, студита, Казимира Шептицького. Архимандрит Климентій (Шептицький): тематичний збірник Святопокровського жіночого монастиря Студійського Уставу. Львів, 2001. Вип. 9. С. 45-46.

Шептицький Іван Лев, граф. Отець Климентій - архимандрит Студитів. Світильник істини: джерела до історії Української католицької богословської академії у Львові 19281929-1944 / ред. П. Синиця. Торонто-Чикаго, 1983. Ч. III. C. $776-782$.

Шептицький Климентій, о. д-р, ігумен студитів. Митрополит Андрей і обновлення Східної чернечої традиції. Богословія. 1926. Т. 4. Кн. 1-4. С. 150-163. 
Шептицький Климентій. Митрополит Андрей і обновлення східної чернечої традиції. Архимандрит Климентій Шептицький: Тематичний збірник Святопокровського жіночого монастиря Студійського уставу, вип. 6, Львів, 2001.

[Шептицький Климентій]. Послання о. Климентія ігумена Святоуспенської Лаври в Уневі для монастирів на Поліссі (16.10.1931). Архимандрит Климентій Шептицький: Тематичний збірник Святопокровського жіночого монастиря Студитського Уставу. 2001. Вип. 6. С. 22.

Шептицький Я. К. Мої спогади про Казимира Шептицького отця Климентія Шептицького. Архимандрит Климентій (Шептицький): тематичний збірник Святопокровського жіночого монастиря Студійського Уставу. Львів, 2001. Вип. 9. С. 22-25.

Шептицький Я. К. Отець Климентій Шептицький. Життєпис на підставі архівних матеріалів родини Шептицьких / перекл. з пол. Надії Пікулик, Любомира Сеника; перкл. з франц. Жінет Максимович. Львів : Свічадо, 1996. 93 с.

Шептицький Я. К. Отець Климентій Шептицький: життєпис на підставі архівних матеріалів родини Шептицьких. Львів: Свічадо, 2016. 112 с.

Шептицький Ян Леон. Спогади про стрийка. Архимандрит Климентій (Шептицький): тематичний збірник Свято-покровського жіночого монастиря Студійського Уставу. Львів, 2001. Вип. 9. С. 27-30.

Шкраб'юк П. Виноградник Господній: Історія життя о. д-ра Йосифа Кладочного / Ін-т українознавства ім. І.Крип'якевича НАН України. Львів: Місіонер, 1995. 280 с.

Яроцький, П. (2001). Католицизм. Історія релізії в Україні: у 10-ти тт. / Редкол.: А. Колодний (голова) та ін. Київ: Укр. Центр духовної культури, 1996-2002. Київ: Світ знань. 598 c.

Korolevskiy K. Metropolite Andre Szeptickyiy (1865-1944). Rome, 1964. 429 с. (Праці УБНТ. Т. XVI-XVII).

Martynyuk T.-T. Caratteristica giuridica dei gradi della consacrazione monastica. II Tipico generale dei monastery studiti nel contesto della tradizione monastica e ded CCEO. Dissertatio ad doctoratum (Pontificium Institutum Orientale. Facultas luris Canonici Orientalis). Leopolis [Lviv, Ukraine], 2010. 311 p.

Руслан Делятинський,

Івано-Франківська академія Івана Золотоустого (м. Івано-Франківськ, Украӥна)

e-mail: r.deliatynskyi@ukr.net, ORCID 0000-0002-6020-7666

Василь Гоголь,

Івано-Франківська академія Івана Золотоустого (м. Івано-Франківськ, Украӥна)

e-mail: otets.vasyl.gogol@ukr.net, ORCID 0000-0001-5236-885X

Аліна Задорожня,

Національний історико-етнографічний заповідник "Переяслав" (м. Переяслав, Україна) e-mail: alina0906@ukr.net, ORCID0000-0002-9537-9054

\section{ПОСТАТЬ БЛАЖЕННОГО КЛИМЕНТІЯ ШЕПТИЦЬКОГО (1869-1951 рр.) У СВІТЛІ СУЧАСНОї ВІТЧИЗНЯНОї ІСТОРІОГРАФІї}

У статті проведено історіографічний аналіз та узагальнення досягнень представників сучасної вітчизняної історіографії (1990-2020), що, враховуючи напрацювання науковців діаспорної історіографії, досліджували життєвий шлях та діяльність блаженного отця Климентія (Казимира) графра Шептицького (1869-1951). 3ауважено, що започатковані діаспорними науковцями дослідження життпису Климентія Шептицького сприяли висвітленню переважно церковно-релігійної діяльності, уникаючи раннього періоду його біографії, а радянська історіографрія хибувала ідеологічними штампами щодо "брата митрополита". Автори підкреслюють, що зростання наукового інтересу до біографії Климентія Шептицького, стимульоване відродженням структур УГКЦ взагалі та студійського чернецтва зокрема, проявилося у двох напрямах: пошуку і систематизації джерел, формуванні спеціалізованих архівів, публікації нових досліджень з історії Студитів та діяльності їх ігумена. Поділяючи дослідження сучасних вітчизяних істориків і богословів на два періоди (у 1990-х і 2000-х роках), автори відзначають, що спершу вони були пов'язані 3 підготовкою до беатифікації Климентія (2001), а потім - 3 популяризацією та поглибленим вивченням його спадщини для використання в практиці меморіалізації та духовному житті Студійського Уставу. Відтак спостерігається зростання кількості та певна диференціація наукових досліджень діяльності блаженного Климентія у період від вступу до монастиря до його заслання i смерті. Сформовані диспропорції у висвітленні його боіграфії, що полягали в "ігноруванні" раннього періоду та створенні нових "міфів", були розв'язані в монографіях В. Чорнописької та І. Матковського, в яких детально з'ясовано його родовід, описано всі етапи життєвого шляху, громадсько-політична та церковно-релігійна діяльність.

Ключові слова: діаспорна історіографрія; радянська історіографрія; сучасна вітчизяна історіографрія; Казимир граф Шептицький; Климентій Шептицький; Студійський устав; блаженний новомученик УГКЦ.

(C) Ruslan Deliatynskyi, Vasyl Gogol, Alina Zadorozhna

Надійшла до редакції: 01.04.2020

Прийнята до друку: 13.04.2020 